\title{
APLIKASI MINYAK KELAPA SAWIT PADA PHOTOVOLTAIC YANG TERINTEGRASI PADA DINDING BANGUNAN SEBAGAI PENDINGIN PASIF UNTUK MENINGKATKAN EFISIENSI DAN MENURUNKAN BEBAN PENDINGIN RUANGAN
}

\author{
A.Yudi Eka Risano', M. Dyan Susila E.S. ${ }^{2}$, Yoga Pratama ${ }^{3}$ \\ Jurusan Teknik Mesin Fakultas Teknik Universitas Lampung \\ JI. Prof. Dr. Sumantri Brojonegoro No. 1, Gedung H Lt.2, Bandar Lampung \\ 35145 Telp.(0721)7479221 \\ E-mail: yudi_95@yahoo.com ${ }^{1}$, dyansusila@yahoo.com², yogapratama123@yahoo.com³
}

\begin{abstract}
Abstrak
Menanggapi isu green building dan penggunaan clean energy yang sangat santer saat ini, pemanfaatan energi terbarukan menjadi meningkat. Penggunaan energi surya menggunakan photovoltaic (PV) pada sistem Building Intergated Photovoltaics (BIPV) akan menambah pasokan listrik dan mengurangi ketergantungan terhadap pembangkit listrik. Menurut M. Farid dan Abhat A. Low dalam jurnal MONEV Muhammad Irsyad, Penambahan Minyak Kelapa Sawit pada Photovoltaic yang Terintegrasi pada Dinding Bangunan untuk Meningkatkan Efisiensi dan Menurunkan Beban Pendingin Ruangan (2012), persoalan tiap kenaikan $1^{\circ} \mathrm{C}$ temperatur PV yang mengurangi efisiensi PV 0,4-0,5\% dapat disiasati dengan integrasi Phase Change Material (PCM). Selain itu dengan sifatnya sebagai pendinginan pasif, masuknya kalor ke dalam ruangan juga akan direduksi. Penelitian ini dilakukan untuk melihat karakteristik efisiensi PV dan perambatan kalor pada ruangan model BIPV yang diintegrasikan dengan PCM CPO. Pengujian dilakukan dengan membandingkan dua model BIPV yang dengan dan tanpa PCM CPO. Variasi dilakukan dengan kemiringan BIPV $45^{\circ}$ dan $30^{\circ}$ masingmasing orientasi timur dan barat. Setelah dilakukan empat variasi percobaan, BIPV dengan kemiringan $30^{\circ}$ lebih unggul dibanding dengan kemiringan $45^{\circ}$. Perbandingan perpindahan panas dinding dalam menuju ruang BIPV dengan PCM CPO kemiringan $30^{\circ}$ orientasi barat lebih signifikan dan stabil, terutama pada intensitas $850 \mathrm{~W} / \mathrm{m}^{2}$ perbandingan panas dari dinding dalam menuju ruang yang sebesar 0,4012 W dapat diredam dengan menggunakan $\mathrm{CPO}$ hanya sebesar 0,2596 W. Kemudian pada puncak perpindahan panas tertinggi dari dinding dalam ke ruang model BIPV tanpa CPO dengan intensitas $923 \mathrm{~W} / \mathrm{m}^{2}$ mencapai 0,43426 W, dengan penambahan PCM CPO hanya 0,25913 W. Perbedaan efisiensi dengan pemakaian PCM CPO juga lebih unggul hingga menaikkan efisiensi 5,75\% saat intensitas $982 \mathrm{~W} / \mathrm{m}^{2}$ sudut penyinaran $120^{\circ}$ dari timur.
\end{abstract}

Kata kunci : green building, clean energy, photovoltaic, Bahan Perubah Fasa, Minyak Kelapa Sawit, pendingin pasif.

\section{Pendahuluan}

Pemanasan global (global warming) semakin terasa di zaman sekarang ini. Matahari memancarkan gelombang radiasinya menembus lapisan atmosfir dan sebagiannya terperangkap di bumi. Peristiwa ini terus terjadi berulang-ulang, hingga suhu rata-rata di permukaan bumi meningkat. Menurut Master plan for development of new and renewable energy (1997), letak Indonesia yang berada pada daerah khatulistiwa, memiliki potensi energi matahari yang sangat besar. Intensitas radiasi matahari di Indonesia mencapai $4,8 \mathrm{kWh} / \mathrm{m}^{2}$ per hari dengan waktu efektif penyinaran 8 $10 \mathrm{jam} / \mathrm{hari}$. Potensi ini baru dimanfaatkan 8 MW [1]. 
Daerah perkotaan banyak sekali gedung bertingkat baik untuk perkantoran maupun pusat bisnis, dengan model dinding beton maupun kaca. Bagian bangunan secara umum mendapat sinar matahari baik secara bergiliran maupun terus menerus sepanjang siang hari. Penyinaran tanpa hambatan ini akan meningkatkan kalor yang masuk ke dalam ruangan.

Menanggapi isu green building dan penggunaan clean energy yang sangat santer saat ini, pemanfaatan energi terbarukan menjadi meningkat. Berdasarkan data cadangan dan produksi energi terbarukan Indonesia 2007, pemanfaatan EBT baru mencapai 5,921 MW (3,64 \%) dari total potensi sebesar 162,770 MW [2].

Penggunaan energi surya menggunakan photovoltaic (PV) pada sistem Building Intergated Photovoltaics (BIPV) akan menambah pasokan listrik dan mengurangi ketergantungan terhadap pembangkit listrik. Namun kenaikan temperatur PV dapat mengurangi efisiensi PV $0,4-0,5 \%$ [3]. Diharapkan dengan pengintegrasian Crude Palm Oil sebagai Phase Change Material (PCM) akan mempertahankan kinerja PV dan mereduksi masuknya kalor ke dalam ruangan.

\section{Metodologi Penelitian}

\section{A. Alat dan Bahan Penelitian}

Adapun alat yang mendukung untuk perancangan, pembuatan dan pengujian ini adalah :

\section{a).Photovoltaics}

Panel Photovoltaic (PV panel) adalah sumber listrik pada sistem pembangkit listrik tenaga surya, material semikonduktor yang mengubah secara langsung energi sinar matahari menjadi energi listrik. Daya listrik yang dihasilkan PV berupa daya DC.

\section{b). Phyranometer/Solarimeter}

Alat ini berfungsi untuk mengukur intensitas cahaya matahari dengan satuan $W / m^{2}$.

c). Multimeter

Alat ini berfungsi untuk mengukur arus (I) dengan satuan Ampere dan tegangan (V) dengan satuan volt.

\section{d) Thermocouple data logger}

Alat ini berfungsi untuk mengukur suhu. Termocouple yang digunakan adalah tipe K. Thermocouple tipe ini dipilih karena paling fleksibel untuk segala keperluan.

Bahan yang digunakan dalam penelitian ini adalah sebagai berikut:

a) Phase Change Material (PCM)

Bahan perubah fasa (Phase Change Material/ PCM) merupakan bahan yang sering digunakan sebagai passive cooling untuk menyerap kalor dengan memanfaatkan panas laten. Pada penelitian ini, bahan PCM yang digunakan adalah CPO (Crude Palm Oil).

b) Ruang Skala Laboratorium

Bangunan ruang yang digunakan dalam pengujian yang akan dilakukan dibuat berskala laboratorium dengan panjang 60 $\mathrm{cm}$, lebar $50 \mathrm{~cm}$, dan tinggi $52 \mathrm{~cm}$. Bangunan dibuat berangkakan kayu dan berdindingkan triplek yang disisipi glasswool. Pada salah satu sisi ruang berdindingkan semen batako yang di buat sedemikian rupa seperti dinding bangunan yang umum dipakai dan bercatkan warna putih. Yang demikian ini dirancang untuk mempermudah perhitungan kalor yang masuk ke dalam ruang.

\section{B. Prosedur Percobaan}

Hal-hal yang perlu dilakukan sebelum pengujian adalah:

a) Merakit dan menyiapkan bentuk model BIPV secara lengkap seperti pada Gambar 1.
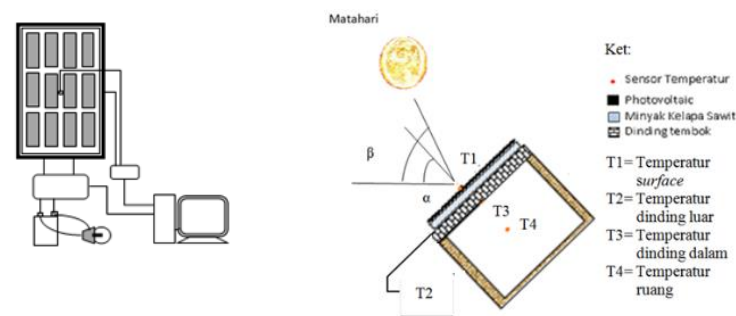

Gambar 1. Posisi penempatan panel surya dan Sistem pengujian di luar ruangan

b) Memasang dan menghidupkan instrumen alat ukur termperatur PV, dinding, dan ruang. Memasang dan menghidupkan alat ukur intensitas cahaya matahari, tegangan, dan arus PV 
untuk model bangunan yang menggunakan PV PCM.

c) Memasang dan menghidupkan alat ukur kecepatan angin dan kelembaban udara.

d) Proses pengambilan data dilakukan setiap 1 jam pada pukul 10:00 hingga pukul 14:00.

e) Menyatukan data untuk tiap-tiap model bangunan.

f) Menentukan perpindahan panas konveksi yang masuk ke dalam ruangan dari dinding bagian dalam [4].

Temperatur film didapat dengan menggunakan persamaan

$$
T_{f}=\frac{T_{s}+T_{\infty}}{2}
$$

Dari tabel Thermophysical Properties of Gases at Atmospheric Pressure karakterisistik udara, dengan menggunakan parameter $\mathrm{T}_{\mathrm{f}}\left({ }^{\circ} \mathrm{K}\right)$, maka didapatkan $\mathrm{k}$ (W/m.K), v ( $\left.\mathrm{m}^{2} / \mathrm{s}\right), \alpha\left(\mathrm{m}^{2} / \mathrm{s}\right), \operatorname{Pr}$, dan $\beta\left(1 / \mathrm{T}_{\mathrm{f}}\right)$,

Kemudian dari properties tabel tersebut, diperoleh Rayleigh Number menggunakan persamaan,

$$
R a_{L}=\frac{g \beta\left(T_{s}-T_{\infty}\right) L^{3}}{\alpha v}
$$

Dengan menggunakan Nusselt Number

$$
N u_{L}=0.68+\frac{0.670 R a_{L}^{1 / 4}}{\left[1+(0.492 / \mathrm{Pr})^{9 / 16}\right]^{4 / 9}}
$$

$h$ dapat diperoleh dengan persamaan,

$$
h=\frac{N u_{L} \cdot k}{L}
$$

Sehingga,

$q_{\text {konv }}=h A\left(T_{s}-T_{\infty}\right)$

g) Menentukan efisiensi PV [5] Daya masukan dihitung dari data intensitas cahaya matahari dan luas penampang PV

$$
P_{\text {in }}=I_{r} \times A
$$

Menentukan daya keluaran dengan mengolah data arus, tegangan, dan Fill Factor PV dengan menggunakan persamaan

$$
\mathrm{P}_{\mathrm{out}}=\mathrm{V}_{\mathrm{oc}} \times \mathrm{I}_{\mathrm{sc}} \times \mathrm{FF}
$$

dimana dalam menentukan Fill Factor

$\mathrm{FF}=\mathrm{V}_{\mathrm{oc}}-\ln \left(\mathrm{V}_{\mathrm{oc}}+0.72\right) / \mathrm{V}_{\mathrm{oc}}+1$

sehingga,

$\eta=\frac{\text { Daya keluaran } P V}{\text { Daya } \text { masukan } P V} \times 100 \%$

h) Mengulangi langkah tersebut untuk bangunan yang terintegrasi PV dengan PCM dan tanpa PCM. Memvariasikan kemiringan bangunan $45^{\circ}$ dan $30^{\circ}$.

i) Pengujian dilakukan dengan memvariasikan arah bangunan, yaitu timur dan barat.

\section{Hasil dan Pembahasan}

\section{A. Hasil}

Tabel 1. Hasil perhitungan BIPV $45^{\circ}$ orientasi timur

\begin{tabular}{|l|c|l|l|l|l|l|l|l|l|l|l|}
\hline Jam & $\begin{array}{c}\text { Sudut } \\
\text { Matahari } \\
\text { dari Timur } \\
\left({ }^{\circ}\right)\end{array}$ & $\begin{array}{l}\text { To } \\
\left({ }^{\circ} \mathrm{C}\right)\end{array}$ & $\begin{array}{l}\mathrm{T1} \\
\left({ }^{\circ} \mathrm{C}\right)\end{array}$ & $\begin{array}{l}\mathrm{T2} \\
\left({ }^{\circ} \mathrm{C}\right)\end{array}$ & $\begin{array}{l}\mathrm{T3} \\
\left({ }^{\circ} \mathrm{C}\right)\end{array}$ & $\begin{array}{l}\mathrm{T4} \\
\left.{ }^{\circ} \mathrm{C}\right)\end{array}$ & $\begin{array}{l}\mathrm{V} \\
\text { (volt) }\end{array}$ & $\begin{array}{l}\mathrm{I} \\
\text { (ampere) }\end{array}$ & $\begin{array}{l}\mathrm{r} \\
\left.\mathrm{W} / \mathrm{m}^{2}\right)\end{array}$ & $\begin{array}{l}\mathrm{q} \\
(\mathrm{W})\end{array}$ & $\begin{array}{l}\eta \\
(\%)\end{array}$ \\
\hline $10: 00$ & 60 & 38,6 & 45,5 & 28,7 & 29,2 & 28,2 & 19,13 & 1,12 & 07 & 0,30 & 10,7 \\
\hline $11: 00$ & 75 & 41,1 & 53,8 & 33,8 & 32,5 & 30,6 & 19,17 & 1,07 & 340 & 0,65 & 11,1 \\
\hline $12: 00$ & 90 & 33,8 & 47,9 & 36,9 & 35,8 & 34,2 & 19,05 & 0,42 & 445 & 0,52 & 8,2 \\
\hline $13: 00$ & 105 & 35,0 & 49,0 & 39,0 & 37,4 & 36,3 & 19,30 & 0,46 & 541 & 0,32 & 7,5 \\
\hline $14: 00$ & 120 & 35,4 & 43,1 & 38,1 & 37,9 & 36,7 & 19,25 & 0,30 & 360 & 0,36 & 7,3 \\
\hline
\end{tabular}

Tabel 2. Hasil perhitungan BIPV+PCM $45^{\circ}$ orientasi timur

\begin{tabular}{|l|c|l|l|l|l|l|l|l|l|l|l|}
\hline Iam & $\begin{array}{c}\text { Sudut } \\
\text { Matahari } \\
\text { dari Timur } \\
\left({ }^{\circ}\right)\end{array}$ & $\begin{array}{l}\text { To } \\
\left({ }^{\circ} \mathrm{C}\right)\end{array}$ & $\begin{array}{l}\mathrm{T} 1 \\
\left({ }^{\circ} \mathrm{C}\right)\end{array}$ & $\begin{array}{l}\mathrm{T} 2 \\
\left({ }^{\circ} \mathrm{C}\right)\end{array}$ & $\begin{array}{l}\mathrm{T3} \\
\left.{ }^{\circ} \mathrm{C}\right)\end{array}$ & $\begin{array}{l}\mathrm{T} 4 \\
\left({ }^{\circ} \mathrm{C}\right)\end{array}$ & $\begin{array}{l}\mathrm{V} \\
\text { (volt) }\end{array}$ & $\begin{array}{l}\mathrm{I} \\
(\text { ampere })\end{array}$ & $\begin{array}{l}\mathrm{r} \\
\left.\mathrm{W} / \mathrm{m}^{2}\right)\end{array}$ & $\begin{array}{l}\mathrm{q} \\
(\mathrm{W})\end{array}$ & $\begin{array}{l}\eta \\
(\%)\end{array}$ \\
\hline $10: 00$ & 60 & 38,6 & 45 & 26,5 & 26 & 25 & 19,5 & 1,17 & 07 & 0,30 & 11,5 \\
\hline $11: 00$ & 75 & 41,1 & 50,2 & 28,6 & 27,3 & 26,1 & 19,24 & 1,13 & 340 & 0,37 & 11,8 \\
\hline $12: 00$ & 90 & 33,8 & 44 & 31,5 & 30 & 28,7 & 19,05 & 0,46 & 445 & 0,41 & 9 \\
\hline $13: 00$ & 105 & 35,0 & 45,5 & 32,7 & 30,3 & 29,7 & 19,35 & 0,49 & 541 & 0,16 & 8,0 \\
\hline $14: 00$ & 120 & 35,4 & 41 & 33,5 & 30,8 & 30,4 & 19,25 & 0,32 & 360 & 0,09 & 7,8 \\
\hline
\end{tabular}

\begin{tabular}{|c|c|c|c|c|c|c|c|c|c|c|c|}
\hline Jam & $\begin{array}{c}\text { Sudut } \\
\text { Matahari } \\
\text { dari Timur } \\
\left({ }^{\circ}\right)\end{array}$ & $\begin{array}{l}\Gamma \infty \\
\left({ }^{\circ} \mathrm{C}\right)\end{array}$ & $\begin{array}{l}\mathrm{T} 1 \\
\left({ }^{\circ} \mathrm{C}\right)\end{array}$ & $\begin{array}{l}\mathrm{T} 2 \\
\left({ }^{\circ} \mathrm{C}\right)\end{array}$ & $\begin{array}{l}T 3 \\
\left({ }^{\circ} \mathrm{C}\right)\end{array}$ & $\begin{array}{l}\mathrm{T} 4 \\
\left({ }^{\circ} \mathrm{C}\right)\end{array}$ & $\begin{array}{l}V \\
\text { (volt) }\end{array}$ & I & $\begin{array}{l}\mathrm{r} \\
\left.\mathrm{W} / \mathrm{m}^{2}\right)\end{array}$ & $\begin{array}{l}\mathrm{q} \\
(\mathrm{W})\end{array}$ & $\begin{array}{l}\eta \\
(\%)\end{array}$ \\
\hline 10:00 & 60 & 35 & 42,3 & 26,1 & 27,1 & 27,1 & 19,12 & 1,46 & 973 & 0,30 & 11,5 \\
\hline $11: 00$ & 75 & 37,4 & 56,1 & 30,2 & 27,8 & 27,8 & 19,21 & 1,32 & 924 & 0,37 & 11,8 \\
\hline $12: 00$ & 90 & 38,6 & 48 & 34,6 & 29,5 & 29,5 & 18,74 & 0,91 & 737 & 0,41 & 9 \\
\hline $13: 00$ & 105 & 39,9 & 51,7 & 36,6 & 30,3 & 29,3 & 19,73 & 1,02 & $\$ 27$ & 0,16 & 8,0 \\
\hline $14: 00$ & 120 & 43,1 & 50,4 & 37,5 & 31,2 & 30,5 & 19,27 & 0,74 & 545 & 0,09 & 7,8 \\
\hline
\end{tabular}

Tabel 3. Hasil perhitungan BIPV $30^{\circ}$ orientasi timur

\begin{tabular}{|l|c|l|l|l|l|l|l|l|l|l|l|}
\hline Jam & $\begin{array}{c}\text { Sudut } \\
\text { Matahari } \\
\text { dari Timur } \\
\left({ }^{\circ}\right)\end{array}$ & $\begin{array}{l}\text { To } \\
\left({ }^{\circ} \mathrm{C}\right)\end{array}$ & $\begin{array}{l}\mathrm{T1} \\
\left({ }^{\circ} \mathrm{C}\right)\end{array}$ & $\begin{array}{l}\mathrm{T2} \\
\left({ }^{\circ} \mathrm{C}\right)\end{array}$ & $\begin{array}{l}\mathrm{T3} \\
\left({ }^{\circ} \mathrm{C}\right)\end{array}$ & $\begin{array}{l}\mathrm{T4} \\
\left.{ }^{\circ} \mathrm{C}\right)\end{array}$ & $\begin{array}{l}\mathrm{V} \\
\text { (volt) }\end{array}$ & $\begin{array}{l}\mathrm{I} \\
\text { (ampere) }\end{array}$ & $\begin{array}{l}\mathrm{r} \\
\left.\mathrm{W} / \mathrm{m}^{2}\right)\end{array}$ & $\begin{array}{l}\mathrm{q} \\
(\mathrm{W})\end{array}$ & $\begin{array}{l}\eta \\
\%)\end{array}$ \\
\hline $10: 00$ & 60 & 35 & 43,8 & 28,5 & 28,2 & 26,9 & 19,1 & 1,32 & 773 & 0,26 & 11,6 \\
\hline $11: 00$ & 75 & 37,4 & 60,1 & 34,6 & 31,7 & 29,9 & 19,2 & 1,26 & 24 & 0,61 & 12,5 \\
\hline $12: 00$ & 90 & 38,6 & 51,4 & 39 & 34,3 & 32,4 & 19,67 & 0,94 & 37 & 0,65 & 11 \\
\hline $13: 00$ & 105 & 39,9 & 51,4 & 38,8 & 34 & 32,6 & 19,64 & 0,94 & 327 & 0,44 & 10,2 \\
\hline $14: 00$ & 120 & 43,1 & 50,7 & 40,6 & 36,7 & 35,5 & 19,21 & 0,66 & 545 & 0,36 & 8,9 \\
\hline
\end{tabular}

Tabel 4. Hasil perhitungan BIPV+PCM $30^{\circ}$ orientasi timur 
Tabel 5. Hasil perhitungan BIPV $45^{\circ}$ orientasi barat

\begin{tabular}{|l|c|l|l|l|l|l|l|l|l|l|l|}
\hline Jam & $\begin{array}{c}\text { Sudut } \\
\text { Matahari } \\
\text { dari Timur } \\
\left({ }^{\circ}\right)\end{array}$ & $\begin{array}{l}\text { To } \\
\left({ }^{\circ} \mathrm{C}\right)\end{array}$ & $\begin{array}{l}\mathrm{T} 1 \\
\left({ }^{\circ} \mathrm{C}\right)\end{array}$ & $\begin{array}{l}\mathrm{T} 2 \\
\left.{ }^{\circ} \mathrm{C}\right)\end{array}$ & $\begin{array}{l}\mathrm{T} 3 \\
\left({ }^{\circ} \mathrm{C}\right)\end{array}$ & $\begin{array}{l}\mathrm{T} 4 \\
\left({ }^{\circ} \mathrm{C}\right)\end{array}$ & $\begin{array}{l}\mathrm{V} \\
(\text { volt })\end{array}$ & $\begin{array}{l}\mathrm{I} \\
(\text { ampere })\end{array}$ & $\begin{array}{l}\mathrm{W} \\
\left.\mathrm{W} / \mathrm{m}^{2}\right)\end{array}$ & $\begin{array}{l}\mathrm{q} \\
(\mathrm{W})\end{array}$ & $\begin{array}{l}\eta \\
\%)\end{array}$ \\
\hline $10: 00$ & 60 & 34,2 & 40,3 & 26,1 & 26,7 & 26,2 & 19,55 & 0,63 & 771 & 0,13 & 9,8 \\
\hline $11: 00$ & 75 & 37 & 46,1 & 29 & 28,2 & 27,5 & 19,59 & 0,77 & 30 & 0,19 & 9,4 \\
\hline $12: 00$ & 90 & 36,6 & 49,5 & 34 & 31 & 30 & 19,56 & 1 & 336 & 0,29 & 10,7 \\
\hline $13: 00$ & 105 & 39,5 & 57,2 & 37,2 & 33,1 & 31,9 & 18,82 & 1,02 & 558 & 0,37 & 10,1 \\
\hline $14: 00$ & 120 & 40,7 & 60,8 & 43,3 & 34,8 & 33,7 & 18,88 & 1,21 & 995 & 0,33 & 10,4 \\
\hline
\end{tabular}

Tabel 6. Hasil perhitungan BIPV+PCM $45^{\circ}$ orientasi barat

\begin{tabular}{|l|c|l|l|l|l|l|l|l|l|l|l|}
\hline Jam & $\begin{array}{c}\text { Sudut } \\
\text { Matahari } \\
\text { dari Timur } \\
\left({ }^{\circ}\right)\end{array}$ & $\begin{array}{l}\text { To } \\
\left({ }^{\circ} \mathrm{C}\right)\end{array}$ & $\begin{array}{l}\mathrm{T} 1 \\
\left({ }^{\circ} \mathrm{C}\right)\end{array}$ & $\begin{array}{l}\mathrm{T2} \\
\left.{ }^{\circ} \mathrm{C}\right)\end{array}$ & $\begin{array}{l}\mathrm{T3} \\
\left({ }^{\circ} \mathrm{C}\right)\end{array}$ & $\begin{array}{l}\mathrm{T} 4 \\
\left({ }^{\circ} \mathrm{C}\right)\end{array}$ & $\begin{array}{l}\mathrm{V} \\
\text { (volt) }\end{array}$ & $\begin{array}{l}\mathrm{Ir} \\
(\text { ampere) }\end{array}$ & $\begin{array}{l}\mathrm{r} \\
\left.\mathrm{W} / \mathrm{m}^{2}\right)\end{array}$ & $\begin{array}{l}\mathrm{q} \\
(\mathrm{W})\end{array}$ & $\begin{array}{l}\eta \\
\%\end{array}$ \\
\hline $10: 00$ & 60 & 34,2 & 40,3 & 25,4 & 26,1 & 25,7 & 19,68 & 0,67 & 771 & 0,09 & 10,6 \\
\hline $11: 00$ & 75 & 37 & 45,8 & 28,5 & 26,5 & 26 & 19,69 & 0,86 & 30 & 0,13 & 10,6 \\
\hline $12: 00$ & 90 & 36,6 & 45,6 & 36,1 & 27 & 26,3 & 19,77 & 1,05 & 336 & 0,19 & 11,4 \\
\hline $13: 00$ & 105 & 39,5 & 52,6 & 33,1 & 30 & 29,2 & 19,45 & 1,14 & 558 & 0,22 & 11,8 \\
\hline $14: 00$ & 120 & 40,7 & 56,6 & 37,9 & 30,6 & 30 & 19,12 & 1,36 & 995 & 0,16 & 11,9 \\
\hline
\end{tabular}

Tabel 7. Hasil perhitungan BIPV $30^{\circ}$ orientasi barat

\begin{tabular}{|c|c|c|c|c|c|c|c|c|c|c|c|}
\hline Jam & $\begin{array}{c}\text { Sudut } \\
\text { Matahari } \\
\text { dari Timur } \\
\left({ }^{\circ}\right)\end{array}$ & $\left(\begin{array}{l}T \infty \\
\left.{ }^{\circ} \mathrm{C}\right)\end{array}\right.$ & $\begin{array}{l}\mathrm{T} 1 \\
\left.{ }^{\circ} \mathrm{C}\right)\end{array}$ & $\begin{array}{l}\text { T2 } \\
\left({ }^{\circ} \mathrm{C}\right)\end{array}$ & $\begin{array}{l}\mid \mathrm{T} 3 \\
\left({ }^{\circ} \mathrm{C}\right)\end{array}$ & $\begin{array}{l}\mathrm{T} 4 \\
\left.{ }^{\circ} \mathrm{C}\right)\end{array}$ & $\begin{array}{l}\mathrm{V} \\
\text { (volt) }\end{array}$ & 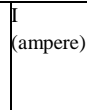 & $\begin{array}{l}\mathrm{r} \\
\left.\mathrm{W} / \mathrm{m}^{2}\right)\end{array}$ & \begin{tabular}{|l}
$\mathrm{q}$ \\
(W)
\end{tabular} & $\begin{array}{l}\eta \\
\%)\end{array}$ \\
\hline 10:00 & 60 & 34,8 & 41,5 & 30,6 & 27,4 & 27 & 19,24 & 0,78 & 522 & 0,1 & 11 \\
\hline 11:00 & 75 & 40,3 & 53,4 & 37,6 & 32 & 31 & 19,4 & 1,06 & 305 & 0,29 & 10,7 \\
\hline $12: 00$ & 90 & 37,4 & 58,2 & 40,7 & 35,5 & 34,2 & 19,24 & 1,16 & 350 & 0,4 & 10,9 \\
\hline 13:00 & 105 & 37,8 & 56,9 & 38,6 & 39 & 37,6 & 19,28 & 1,25 & 923 & 0,43 & 10,9 \\
\hline 14:00 & 120 & 35 & 51 & 38,2 & 38,5 & 37,3 & 19,11 & 1,51 & 982 & 0,36 & 12,2 \\
\hline
\end{tabular}

Tabel 8. Hasil perhitungan BIPV+PCM $30^{\circ}$ orientasi barat

\begin{tabular}{|c|c|c|c|c|c|c|c|c|c|c|c|}
\hline Jam & $\begin{array}{c}\text { Sudut } \\
\text { Matahari } \\
\text { dari Timur } \\
\left({ }^{\circ}\right)\end{array}$ & $\left(\begin{array}{l}\mathrm{T} \infty \\
\left({ }^{\circ} \mathrm{C}\right)\end{array}\right.$ & $\begin{array}{l}\mathrm{T} 1 \\
\left({ }^{\circ} \mathrm{C}\right)\end{array}$ & $\begin{array}{l}\text { T2 } \\
\left.{ }^{\circ} \mathrm{C}\right)\end{array}$ & $\begin{array}{l}\mathrm{T} 3 \\
\left({ }^{\circ} \mathrm{C}\right)\end{array}$ & $\begin{array}{l}\text { T4 } \\
\left({ }^{\circ} \mathrm{C}\right)\end{array}$ & $\begin{array}{l}\mathrm{V} \\
\text { (volt) }\end{array}$ & (ampere) & {$\left[\begin{array}{l}\mathrm{r} \\
\left.\mathrm{W} / \mathrm{m}^{2}\right)\end{array}\right.$} & $\begin{array}{l}\text { q } \\
\text { (W) }\end{array}$ & $\begin{array}{l}\eta \\
(\%)\end{array}$ \\
\hline 10:00 & 60 & 34,2 & 40,7 & 27,6 & 26,6 & 26,1 & 19,19 & 0,78 & $\$ 71$ & 0,13 & 11 \\
\hline 11:00 & 75 & 37 & 48,2 & 36,7 & 27,5 & 26,8 & 19,23 & 0,98 & 30 & 0,19 & 11,6 \\
\hline 12:00 & 90 & 36,6 & 54,6 & 39,1 & 29,6 & 28,7 & 18,95 & 1,08 & $\beta 36$ & 0,26 & 12 \\
\hline 13:00 & 105 & 39,5 & 55,3 & 37 & 30,1 & 29,2 & 19,06 & 1,16 & 358 & 0,26 & 12,3 \\
\hline 14:00 & 120 & 40,7 & 50,7 & 37,8 & 30,8 & 30,1 & 19,02 & 1,26 & 995 & 0,19 & 14,7 \\
\hline
\end{tabular}

\section{B. Pembahasan}

\section{Perpindahan panas.}

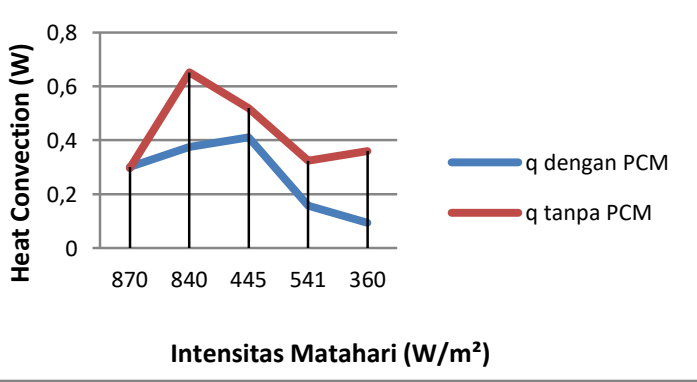

Gambar 2. Grafik Pengaruh PCM terhadap Perpindahan Panas dalam Ruang (q) pada BIPV $45^{\circ}$ menghadap timur.
Pada intensitas $840 \mathrm{~W} / \mathrm{m}^{2}$ panas yang masuk lebih besar yaitu sebesar 0,30031 W dibandingkan dengan penggunaan PCM pada intensitas $870 \mathrm{~W} / \mathrm{m}^{2}$ yaitu sebesar $0.29651 \mathrm{~W}$, kemudian panas yang masuk perlahan menurun ekuivalen dengan intensitas yaitu masing-masing sebesar $0,51921 \mathrm{~W}$ tanpa PCM dan $0.40989 \mathrm{~W}$ dengan PCM, turun menjadi $0,32348 \mathrm{~W}$ tanpa PCM dan $0,15632 \mathrm{~W}$ dengan PCM, hingga 0,35984 $\mathrm{W}$ tanpa PCM dan 0,09432 $\mathrm{W}$ dengan PCM. Intensitas matahari mendekati maksimum untuk sudut kemiringan BIPV $45^{\circ}$ pada intensitas 840 $\mathrm{W} / \mathrm{m}^{2}$. Hal ini menyebakan panas yang masuk langsung diteruskan ke dalam ruangan tanpa ada PCM pereduksi sehingga perbedaan kalor ruangan sangat signifikan.

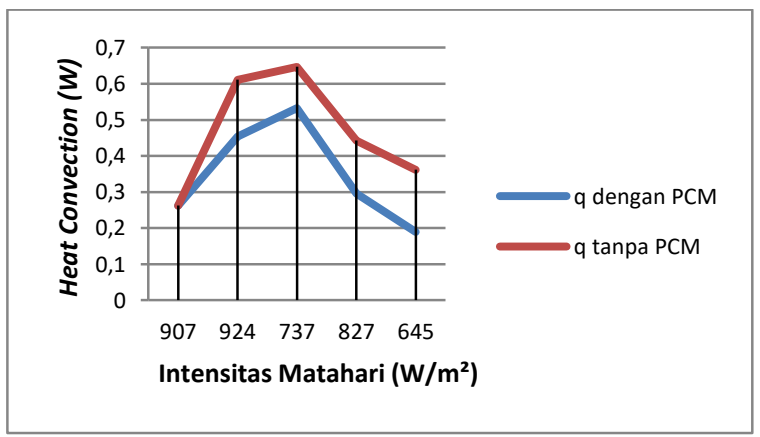

Gambar 3. Grafik Pengaruh PCM terhadap Perpindahan Panas dalam Ruang (q) pada BIPV $30^{\circ}$ menghadap timur.

Jika tidak menggunakan PCM, kalor ruangan mencapai 0.64711 W pada pukul 12:00, sedangkan jika menggunakan PCM kalor ruangan sebesar $0.5321 \mathrm{~W}$. Perbedaan kalor ruangan pada keduanya tidak terlalu signifikan, hal ini dikarenakan material yang digunakan untuk wadah PCM terbuat dari seng yang mempunyai nilai konduktivitas termal $116 \mathrm{~W} / \mathrm{m}^{2}$ sehingga panas yang masuk ke ruangan juga relatif besar. 


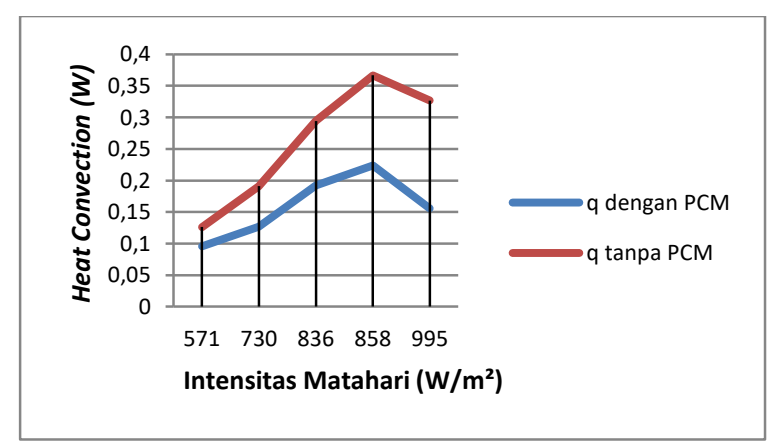

Gambar 4. Grafik Pengaruh PCM terhadap Perpindahan Panas dalam Ruang (q) pada BIPV $45^{\circ}$ menghadap barat.

Perpindahan panas yang terjadi perlahanlahan mengalami peningkatan hingga pada intensitas $858 \mathrm{~W} / \mathrm{m}^{2}$ mengalami sedikit penurunan. Begitu juga dengan penggunaan PCM, perpindahan panas yang terjadi searah dengan tanpa PCM, semakin meningkat hingga intensitas $858 \mathrm{~W} / \mathrm{m}^{2}$. Namun, terbukti panas yang masuk ke ruangan dapat dihambat dan berbedaan kalor yang masuk cukup signifikan dibandingkan dengan BIPV tanpa PCM. Pada intensitas $995 \mathrm{~W} / \mathrm{m}^{2}$ perpindahan kalor yang terjadi sebesar $0,36651 \mathrm{~W}$ hingga $0,32671 \mathrm{~W}$, namun dengan penggunaan PCM CPO perpindahan kalor yang terjadi dapat direduksi menjadi $0,22387 \mathrm{~W}$ hingga $0,15613 \mathrm{~W}$.

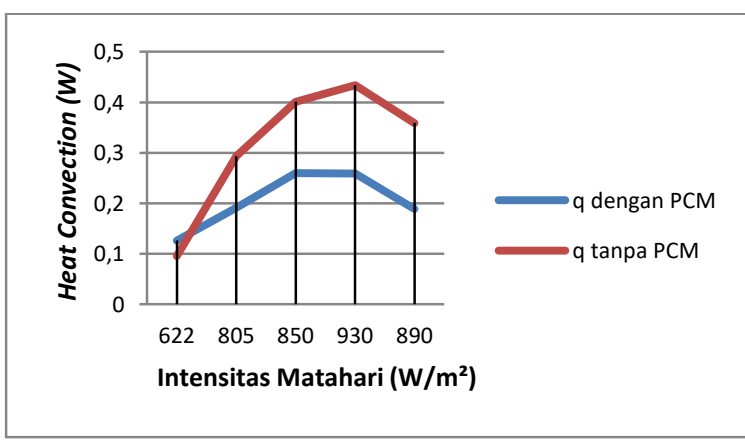

Gambar 5. Grafik Pengaruh PCM terhadap Perpindahan Panas dalaRuang (q) pada BIPV $30^{\circ}$ menghadap barat.

Puncak intensitas maksimum yang masuk ke dalam BIPV melalui PV berada pada kisaran intensitas 850 hingga $930 \mathrm{~W} / \mathrm{m}^{2}$, sehingga panas yang merambat masuk juga besar. Begitu juga dengan penggunaan PCM, perpindahan panas yang terjadi searah dengan tanpa PCM, namun CPO dapat mengendalikan kalor yang diteruskan menuju ruangan. Perbedaan antara yang menggunakan PCM CPO dengan tanpa CPO jauh lebih signifikan. Kalor yang masuk dengan menggunakan PCM CPO dapat direduksi jauh lebih rendah. Perpindahan kalor terjadi pada puncaknya sebesar 0,40124 W hingga 0,43426 W, namun dengan penggunaan PCM CPO perpindahan kalor dapat direduksi dan tetap bertahan dari 0,25964 W hingga 0,25913 W.

Berdasarkan ke empat grafik pengaruh PCM CPO terhadap perpindahan panas di atas, terbukti CPO dapat menghambat panas yang masuk ke ruangan. Pada bangunan yang berorientasi menghadap timur, perpindahan panas yang terjadi meningkat secara signifikan sebesar $0,30031 \mathrm{~W}$ pada intensitas $840 \mathrm{~W} / \mathrm{m}^{2}$ dibandingkan dengan penggunaan PCM hanya sebesar $0.29651 \mathrm{~W}$ pada intensitas $737 \mathrm{~W} / \mathrm{m}^{2}$. Pada kemiringan $30^{\circ}$ perpindahan panas terbesar mencapai $0.64711 \mathrm{~W}$, sedangkan jika menggunakan PCM sebesar $0.5321 \mathrm{~W}$. Sedangkan untuk model BIPV kemiringan $45^{0}$ yang menghadap barat, secara perlahan kalor yang diteruskan ke dalam ruang masih meningkat dari intensitas $850 \mathrm{~W} / \mathrm{m}^{2}$ ke $930 \mathrm{~W} / \mathrm{m}^{2}$. Dibandingkan dengan pemakaian $\mathrm{CPO}$, perpindahan panas yang terjadi pada kemiringan $30^{\circ}$ lebih konstan dan lebih teratur.

\section{Efisiensi}

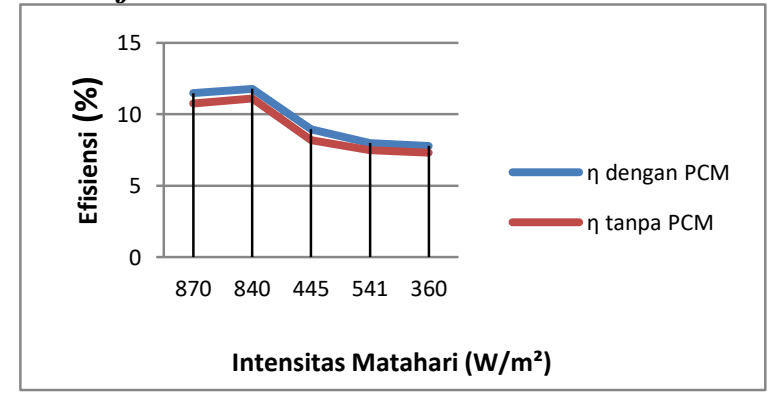

Gambar 6. Grafik Pengaruh Pemasangan PCM terhadap Efisiensi PV pada BIPV $45^{\circ}$ menghadap timur.

Pada intensitas $870 \mathrm{~W} / \mathrm{m}^{2}$ dan $840 \mathrm{~W} / \mathrm{m}^{2}$, efisiensi yang dihasilkan cukup tinggi yaitu hingga $26 \%$, pemakaian CPO menaikkan 
efisiensi $1 \%$ menjadi $27 \%$. Hingga pada pukul berikutnya efisiensi menurun seiring sudut penyinaran matahari yang semakin menjauh dari posisi tegak lurus permukaan PV.

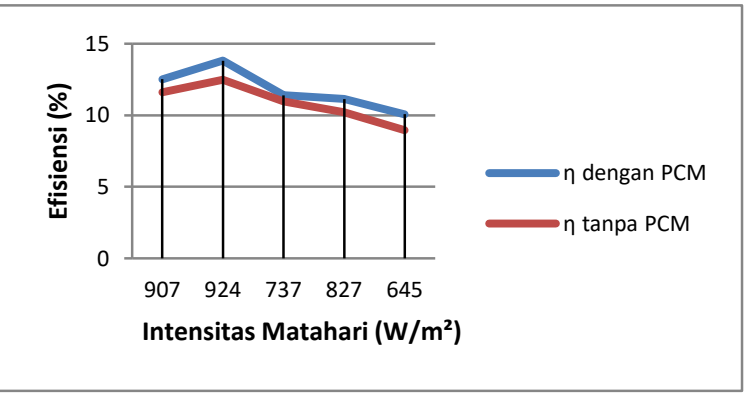

Gambar 7. Grafik Pengaruh Pemasangan PCM terhadap Efisiensi PV pada BIPV $30^{\circ}$ menghadap timur.

Efisiensi awal yang dihasilkan cukup tinggi yaitu hingga 29\%, pemakaian CPO menaikkan $2 \%$ efisiensi menjadi $31 \%$ sampai $32 \%$ pada intensitas $924 \mathrm{~W} / \mathrm{m}^{2}$. Selanjutnya efisiensi menurun seiring sudut penyinaran matahari yang semakin menjauh dari posisi tegak lurus permukaan PV.

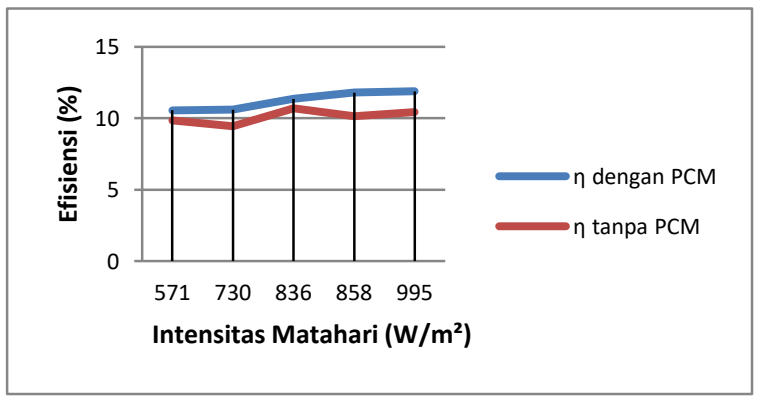

Gambar 8. Grafik Pengaruh Pemasangan PCM terhadap Efisiensi PV pada BIPV $45^{\circ}$ menghadap barat.

Pemakaian CPO mempertahankan efisiensi menjadi tetap stabil. Dengan menggunakan CPO efisiensi semakin meningkat hingga $27 \%$ saat intensitas $995 \mathrm{~W} / \mathrm{m}^{2}$, sedangkan jika tidak menggunakan $\mathrm{CPO}$, efisiensi hanya mencapai $24 \%$ pada pukul $995 \mathrm{~W} / \mathrm{m}^{2}$.

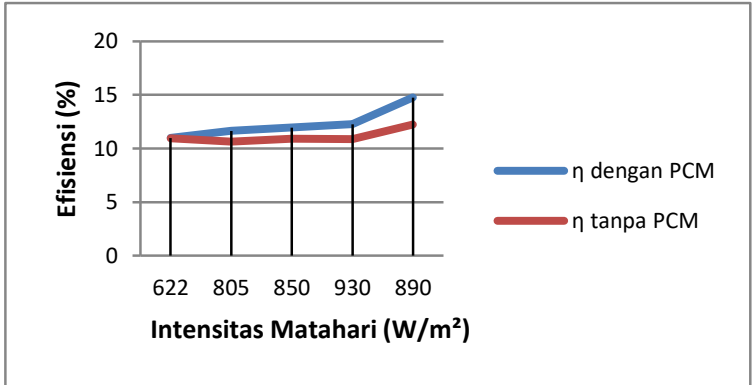

Gambar 9. Grafik Pengaruh Pemasangan PCM terhadap Efisiensi PV pada BIPV $30^{\circ}$ menghadap barat.

Dari waktu ke waktu efisiensi semakin meningkat hingga saat intensitas $890 \mathrm{~W} / \mathrm{m}^{2}$, begitu juga dengan pemakaian $\mathrm{CPO}$, dapat dilihat pada grafik pemakaian CPO tetap meningkatkan efisiensi CPO dan meningkat pada intensitas $890 \mathrm{~W} / \mathrm{m}^{2}$, hal ini dikarenakan posisi arah penyinaran matahari yang paling optimum adalah pukul 14:00 saat intensitas $890 \mathrm{~W} / \mathrm{m}^{2}$ yaitu $34 \%$ sedangkan jika tidak menggunakan $\mathrm{CPO}$ hanya sebesar $28 \%$.

Sudut penyinaran yang berubah tiap jamnya mempengaruhi intensitas dan temperatur pada permukaan PV. Ketika intensitas semakin besar maka temperatur akan equivalent dengan intensitas tersebut dan mempengaruhi voltase serta arus keluaran. Sejalan dengan kenaikan itu maka efisiensi pun akan berubah. Hal ini dikarenakan kenaikan temperatur akan menurunkan tegangan output namun menaikkan arus outputnya sehingga daya keluarannyapun akan turun. Sebaliknya, apabila daya keluarannya turun maka dengan sendirinnya efisiensinya juga akan turun. Oleh karena itu, penambahan PCM CPO berguna untuk memaksimalkan unjuk kerja PV dengan menaikkan efisiensi PV. Di sisi yang sama, PCM ini pun berguna sebagai pendingin pasif (Passive Cooling) bagi PV maupun ruang dalam bangunan.

\section{Kesimpulan}

Berdasarkan hasil penelitian dan pengujian yang dilakukan terhadap BIPV diperoleh data-data dari hasil pengujian tersebut dan telah dibahas dalam 
pembahasan, maka dapat diambil beberapa kesimpulan sebagai berikut:

1. Dari hasil penelitian pengaruh panjang serat terhadap sifat mekanis dan fisik komposit berpenguat serat ijuk dengan matrik epoxy dapat diambil kesimpulan : Perpindahan panas pada ruangan dipengaruhi oleh suhu ruangan yang dikonveksikan dari dinding. Semakin tingginya suhu, semakin besar pula panas yang masuk ke ruangan.

2. Pada BIPV orientasi timur, perpindahan panas yang terjadi mulai meningkat secara signifikan pada saat intensitas 840 $\mathrm{W} / \mathrm{m}^{2}$ untuk kemiringan $45^{\circ}$ dan 737 $\mathrm{W} / \mathrm{m}^{2}$ untuk kemiringan $30 \mathrm{~W} / \mathrm{m}^{2}$. Sedangkan pada orientasi barat, perpindahan panas yang terjadi secara perlahan meningkat hingga puncaknya pada intensitas $858 \mathrm{~W} / \mathrm{m}^{2}$ untuk $45^{\circ}$ dan $930 \mathrm{~W} / \mathrm{m}^{2}$ untuk $30^{\circ}$. Hal ini disebabkan karena posisi penyinaran matahari ke PV mendekati tegak lurus.

3. PCM CPO dapat mereduksi perpindahan panas yang merambat ke dalam ruang, dari grafik dapat dilihat bahwa perbedaan yang cukup signifikan dan konstan didapat pada posisi BIPV dengan kemiringan $30^{\circ}$ menghadap barat.

4. Semakin mendekati tegak lurus dengan PV, efisiensi PV semakin besar. Hal ini dikarenakan tegangan yang dihasilkan semakin besar seiring dengan besarnya intensitas matahari sebagai daya input yang masuk. Penggunaan PCM meningkatkan efisiensi PV dengan menyerap energi panas berlebih pada PV selama perubahan fasa.

\section{Daftar Pustaka}

[1]. Master plan for development of new and renewable energy. 1997. Directorate of Electricity and Energy Development, (DESDM).

[2]. Master plan for development of new and renewable energy. 2007. Directorate of Electricity and

\section{Energy Development, (DESDM).}

[3]. Irsyad, Muhammad dan Susila, M Dyan. 2012. Penambahan Minyak Kelapa Sawit pada Photovoltaic yang Terintegrasi pada Dinding Bangunan untuk Meningkatkan Efisiensi dan Menurunkan Beban Pendingin Ruangan, Jurnal MONEV, Universitas Lampung, Lampung.

[4]. Holman, J.P. 1983. Heat Transfer sixth edition. McGraw Hill. London

[5]. Muchammad dan Yohana, Eflita. 2010. Pengaruh suhu permukaan photovoltaic 